\title{
Effect of Environmental Sulfur on the Structure of Alumina \\ Scales Formed on Ni-base Alloys
}

\author{
Xu Liu ${ }^{1}$, Cecile Bonifacio ${ }^{2}$, Judith C. Yang $^{2}$, Peter Ercius $^{3}$ and Brian Gleeson ${ }^{1}$ \\ ${ }^{1}$ Materials Science and Engineering, University of Pittsburgh, Pittsburgh, PA 15261, \\ USA. \\ ${ }^{2}$ Chemical and Petroleum Engineering and Physics, University of Pittsburgh, Pittsburgh, \\ PA 15261, USA. \\ ${ }^{3}$ National Center for Electron Microscopy, Lawrence Berkeley National Laboratory, \\ Berkeley, CA, 94720, USA. \\ *Corresponding author: xul12@pitt.edu
}

\begin{abstract}
Short-term oxidation exposures of an alumina-scale forming $\gamma^{\prime}-\mathrm{Ni}_{3} \mathrm{Al}$-based model alloy in air and $\mathrm{O}_{2}+0.1 \% \mathrm{SO}_{2}$ at $900^{\circ} \mathrm{C}$ revealed that the presence of sulfur can affect the kinetic competition between the $\theta$ and $\alpha$ structural isomorphs of $\mathrm{Al}_{2} \mathrm{O}_{3}$. After 2 hours exposure, metastable $\theta-\mathrm{Al}_{2} \mathrm{O}_{3}$ growth predominated in air alone; whereas, a much larger percentage of stable $\alpha-\mathrm{Al}_{2} \mathrm{O}_{3}$ formed during oxidation in $\mathrm{O}_{2}+0.1 \% \mathrm{SO}_{2}$. This promotion of $\alpha-\mathrm{Al}_{2} \mathrm{O}_{3}$ establishment was due to sulfur enrichment on the alloy surface, which occurred even when samples were exposed to $\mathrm{O}_{2}+0.1 \% \mathrm{SO}_{2}$ in a low-temperature, pre-test position $\left(\sim 150^{\circ} \mathrm{C}\right)$, i.e., prior to insertion into the hot zone. It was determined from XPS measurements that the sulfur was mainly in the $S^{6+}$ valence state and, correspondingly, in the form of $\mathrm{NiSO}_{4}$. Cross-sectional scanning transmission electron
\end{abstract}


microscopy (STEM) using energy-dispersive X-ray spectroscopy (EDS) corroborated the XPS results by detecting that a $\sim 20 \mathrm{~nm}$ zone of sulfur enrichment within the surface region of a $\sim 90 \mathrm{~nm}$ oxygen-rich layer formed during the pre-test exposure. A systematic explanation for this intriguing observation of sulfur promoting $\alpha-\mathrm{Al}_{2} \mathrm{O}_{3}$ establishment is provided from the perspective of kinetics competition between $\theta$ and $\alpha$. This explanation was supported by kinetic calculations and complementary tests in a low $\mathrm{p}_{\mathrm{O}_{2}}$ atmosphere.

Key words: sulfur, alumina, kinetic competition, hot corrosion, surface enrichment

\section{Introduction}

Sulfur in various forms is found in the environments of a number of applications in which alloys and metallic coatings are exposed to high temperatures. Environmental sources of sulfur include the combustion of low- and high-grade fuel, sulfate deposits such as $\mathrm{Na}_{2} \mathrm{SO}_{4}, \mathrm{MgSO}_{4}, \mathrm{CaSO}_{4}$ or some combination of these in hot corrosion conditions, and environmental $\mathrm{SO}_{2}$ pollution. Quite a variation in environmental $\mathrm{SO}_{2}$ content can be detected around the world [1], with certain developing regions reporting transient levels up to about $0.1 \mathrm{ppm}$ [2]. Indeed, $\mathrm{SO}_{2}$ is an important variable in saltinduced hot corrosion, which is a very aggressive mode of attack causing failures of many turbine components in the field [3]. It is well established that the extent of attack incurred during low-temperature $\left(\sim 700^{\circ} \mathrm{C}\right)$ hot corrosion depends significantly on the $\mathrm{SO}_{2}$ content in the environment. Moreover, the presence of environmental $\mathrm{SO}_{2}$ can also induce extensive internal sulfidation in conjunction with hot-corrosion attack [4]. 
Alloys and coatings in sulfur-bearing environments often rely on the formation of an alumina scale for protection. The establishment and growth of an alumina scale may be complicated due to alumina having a number of crystalline polymorphs, namely $\gamma-, \delta$, $\eta-, \theta-$, and $\alpha$-alumina [5]. Ideally, a continuous and adherent scale comprised of $\alpha-\mathrm{Al}_{2} \mathrm{O}_{3}$ is preferred because this oxide is the most stable thermodynamically and is also the slowest growing [6]. However, during the initial stages of oxidation, particularly at temperatures below about $1050^{\circ} \mathrm{C}$ and for Ni-base alloys, faster-growing metastable $\mathrm{Al}_{2} \mathrm{O}_{3}$ structures $\left(\gamma\right.$ - and/or $\left.\theta-\mathrm{Al}_{2} \mathrm{O}_{3}\right)$ usually predominate [7]. The metastable forms of $\mathrm{Al}_{2} \mathrm{O}_{3}$, which have a relatively open structure, grow much more rapidly than $\alpha-\mathrm{Al}_{2} \mathrm{O}_{3}$ and will usually transform to the latter with extended exposure. Concurrent with this metastable-to- $\alpha$ transformation is an approximately two orders of magnitude decrease in oxidation rate $[7,8]$ and a $\sim 8-10 \%$ volume reduction [6]. The latter can lead to cracking within the scale [8-10]. These changes can largely affect the protectiveness of the alumina scale to the extent that the rapid establishment of $\alpha-\mathrm{Al}_{2} \mathrm{O}_{3}$, free of metastable-tostable transformation(s), is preferred.

Alumina phase transformation in thermally grown scales has been the subject of extensive investigation $[7,8,11,12]$ since it was first reported [8] in the context of scaling. Most investigations have focused on the effects of alloying elements on the transformation in air or pure $\mathrm{O}_{2}$. Alloy elements such as $\mathrm{Cr}$ [7], $\mathrm{Ti}$ [12], Fe [13] have been found to promote the $\theta-\mathrm{Al}_{2} \mathrm{O}_{3} \rightarrow \alpha-\mathrm{Al}_{2} \mathrm{O}_{3}$ transformation; whereas, $\mathrm{Zr}$ [8], La, Hf[14], Si [15], Pt[16, 17], Y[18-21] have been reported to delay this transformation. A few investigations have dealt with the environmental effects such as water vapor [22-25] and the results are not conclusive. Chevalier et al. [23] and Zhou et al. [22] reported that the 
presence of water vapor promoted the $\theta \rightarrow \alpha$ on the $\mathrm{Fe}_{3} \mathrm{Al}$ intermetallic and $\mathrm{NiAl}$. By contrast, Liu et al. $[24,25]$ studied the oxidation of commercial FeCrAl alloys in $\mathrm{O}_{2}+$ $\mathrm{H}_{2} \mathrm{O}$ and found that water vapor slows $\gamma-\mathrm{Al}_{2} \mathrm{O}_{3} \rightarrow \alpha-\mathrm{Al}_{2} \mathrm{O}_{3}$ transformation.

In applications related to hot corrosion, an alumina scale can form under conditions in which metastable and stable aluminas may co-exist. Recent research [26, 27] has reported that a small amount of sulfur in the atmosphere can promote metastableto- $\alpha$ transformation. This observation was first reported for $\beta$-NiAl-based alloys [27]. Specifically, Ni-46Al-5Pt (in at. \%) coupons were oxidized in air and $\mathrm{O}_{2}+0.1 \% \mathrm{SO}_{2}$ at $900^{\circ} \mathrm{C}$ for 100 hours. It was found that an exclusive $\theta-\mathrm{Al}_{2} \mathrm{O}_{3}$ scale formed on the airexposed coupon; while, $\alpha-\mathrm{Al}_{2} \mathrm{O}_{3}$ predominated on the coupon exposed to the $\mathrm{O}_{2}+0.1 \% \mathrm{SO}_{2}$. Similar observations were subsequently observed for exposures of $\gamma^{\prime}-$ $\mathrm{Ni}_{3} \mathrm{Al}$-based systems after 20 hours of oxidation at $900^{\circ} \mathrm{C}$ in air, air with $\mathrm{Na}_{2} \mathrm{SO}_{4}$ deposit, and $\mathrm{O}_{2}+0.1 \% \mathrm{SO}_{2}$ [26]. A mechanistic understanding of the sulfur effect on alumina phase transformation is still lacking and forms the main aim of the present study.

\section{Experimental Procedures}

A model alloy of nominal composition Ni-20Al-5Cr-0.05Hf-0.05Y at.\% was prepared at the Ames Laboratory's Materials Preparation Center [28] by Ar-arc melting the individual powder constituents followed by drop-casting to form a $\sim 40 \mathrm{~g} 10-\mathrm{mm}$ diameter rod. The as-cast rod was then homogenized in vacuum at $1200^{\circ} \mathrm{C}$ for $48 \mathrm{~h}$. The final structure was single-phase $\gamma^{\prime}-\mathrm{Ni}_{3} \mathrm{Al}$, as determined by optical microscopy and X-ray diffraction. The heat-treated rod was then cut to produce 1-mm thick disks. Before testing, the sample disks were abraded to a P1200-grit finish using SiC paper and then ultrasonically cleaned in acetone. 
Oxidation tests in air were conducted using a horizontal resistance-heated tube furnace. The furnace temperature was calibrated prior to any testing. For a given test, the furnace was initially heated to the target exposure temperature and held for about two hours. The sample, which was contained in an alumina boat, was kept outside of the hot zone during this pre-heating period. Thermal-exposure testing commenced by manually pushing the sample boat into the hot-zone using a metallic push-rod.

Oxidation tests in $\mathrm{O}_{2}-\mathrm{SO}_{2}$ atmospheres were also conducted using a horizontal resistance-heated tube furnace that allowed for the flowing through of a controlled atmosphere (i.e., a closed system was used). Figure 1 shows the schematics of sulfidation apparatus setup. Before testing, the samples were kept near the end of the furnace tube (pre-test position) while the hot-zone was heated to the test temperature of $900^{\circ} \mathrm{C}$. The maximum temperature of the samples during this heating period was measured using a thermocouple to be $\sim 150^{\circ} \mathrm{C}$. The furnace tube was first flushed with pure Ar for two hours and then flushed overnight with the $\mathrm{O}_{2}+0.1 \% \mathrm{SO}_{2}$ reactant gas mix. The reactant gas was passed through a platinized honeycomb ceria-based catalyst prior to reaching the hot zone. This was done to equilibrate the gas mixture. The equilibrium gas compositions were calculated using HSC chemistry software[29] and the results are shown in Table 1. After following this procedure to establish the reacting atmosphere, the samples were pushed into the hot zone of the furnace and isothermally exposed for a fixed period. During oxidation exposure, the flow rate of the reactant gas was $12.5 \mathrm{~cm}^{3} / \mathrm{min}$, which corresponded to a linear velocity of $0.62 \mathrm{~cm} / \mathrm{min}$. At the completion of a given exposure period, the sample was removed from the hot zone and allowed to cool naturally to room temperature. 
Table 1 Equilibrium gas composition at the exposure temperature of $900^{\circ} \mathrm{C}$

\begin{tabular}{|c|c|c|}
\hline Flowing gas & Temperature & Equilibrium gas composition* \\
\hline $\mathrm{O}_{2}+1000 \mathrm{ppm} \mathrm{SO} \mathrm{S}_{2}$ & $900^{\circ} \mathrm{C}$ & $\begin{array}{c}\mathrm{P}_{\mathrm{S}_{2}}=3.7 \times 10^{-16} \mathrm{~atm} ; \mathrm{P}_{\mathrm{O}_{2}}=0.999 \mathrm{~atm} ; \\
\mathrm{Pso}_{3}=2.5 \times 10^{-4} \mathrm{~atm} ; \mathrm{Pso}_{2}=7.5 \times 10^{-4} \mathrm{~atm}\end{array}$ \\
\hline
\end{tabular}

*Equilibrium calculations for catalyzed gases allow for $\mathrm{SO}_{3}$ formation

Photo-stimulated luminescence spectroscopy (PSLS) was used to distinguish $\theta$ $\mathrm{Al}_{2} \mathrm{O}_{3}$ from $\alpha-\mathrm{Al}_{2} \mathrm{O}_{3}$ in the thin oxide scales that formed. The PSLS measurements were made using a LabRam ${ }^{\mathrm{TM}}$ Confocal Raman Microscope (Jobin-Yvon/Horiba, Edison, NJ0) [30]. $\alpha-\mathrm{Al}_{2} \mathrm{O}_{3}$ is known to strongly fluoresce in response to visible laser illumination if trace quantities of chromium are present, giving a peak doublet (R1-R2) at around 693 $\mathrm{nm}$ [31]. The $\theta-\mathrm{Al}_{2} \mathrm{O}_{3}$ peak doublet (T1-T2) is blue-shifted from that of $\alpha$ by approximately $10 \mathrm{~nm}$ [32]. The origin of the abovementioned luminescence in alumina is due to the photo-stimulation and subsequent radiative decay of excited $\mathrm{d}^{3}$ electrons associated with the substitutional $\mathrm{Cr}^{3+}$ ions located on octahedral sites of both $\theta$ and $\alpha$ [9]. Fitting of the spectra was achieved using Renishaw's WiRE v3.2 software to determine the contributing intensity and positions of the R1-R2 and T1-T2 peaks.

X-ray photoelectron spectroscopy (XPS) was used to obtain surface-state information of the exposed samples, while scanning transmission electron microscopy (STEM) was used to characterize cross-sections of the surface regions. TEM crosssection samples were prepared by the conventional method of cutting, grinding and ion thinning. The alloy samples were cut into small squares and polished to a size of $0.5 \times 0.5 \mathrm{~mm}$. A stack of two samples was prepared by gluing (M-Bond610 glue) the small pieces together with the region of interest, i.e., surface layer, from one sample placed on 
top and facing the surface layer of the other sample. The prepared couple was then inserted into a $3 \mathrm{~mm}$ brass tube. A resulting $3 \mathrm{~mm}$ disk or slice was mechanically polished using the Allied Multiprep Polishing system on diamond lapping films of decreasing grit size $(30 \mu \mathrm{m}$ to $0.1 \mu \mathrm{m})$ to $40 \mu \mathrm{m}$ thickness. Electron transparent samples were subsequently obtained by ion milling with argon ions in a Gatan Precision Ion Polishing System at $4 \mathrm{keV}$ to $100 \mathrm{eV}$ for a total of 3 hours at $-100^{\circ} \mathrm{C}$. The chemical composition profiles across the interface of the sample were obtained by spatially resolved electron energy-loss spectroscopy (EELS) and energy-dispersive X-ray spectroscopy (EDS). EELS line scans were acquired using an FEI F20 UT Tecnai TEM/STEM at $200 \mathrm{KeV}$ equipped with a Gatan Tridiem spectrometer. The EDS

elemental mapping was done using a ChemiSTEM ${ }^{\mathrm{TM}}$ system with FEI Super X quad windowless detectors attached to an FEI Titan TEM/STEM microscope operated at 200 KeV. High angle annular dark field (HAADF) imaging was performed while simultaneously acquiring EELS line scans or EDS elemental maps.

\section{Results}

1. $\gamma^{\prime}-\mathrm{Ni}_{3} \mathrm{Al}$-based model alloy: $900^{\circ} \mathrm{C}$ oxidation in air and $\mathrm{O}_{2}+1000 \mathrm{ppm} \mathrm{SO}_{2}$

To understand how establishment of an $\alpha-\mathrm{Al}_{2} \mathrm{O}_{3}$ scale can be promoted in the presence of sulfur [26, 27], short-term oxidation tests were conducted in air and $\mathrm{O}_{2}+0.1 \% \mathrm{SO}_{2}$ at $900^{\circ} \mathrm{C}$. The $\gamma^{\prime}$-based model alloy sample was exposed to $\mathrm{O}_{2}+0.1 \% \mathrm{SO}_{2}$ and air for 1, 2, 5, 10 and 20 hours. An individual sample was used for each exposure. Representative corresponding PSLS spectra are shown in Figure 2 for air oxidation and in Figure 3 for oxidation in $\mathrm{O}_{2}+0.1 \% \mathrm{SO}_{2}$. Overall, a luminescence spectrum for $\alpha-\mathrm{Al}_{2} \mathrm{O}_{3}$ consisting of an R1-R2 doublet was detected at the wavelengths of $693 \mathrm{~nm}$ and $695 \mathrm{~nm}$, 
respectively. The relative positions of $\mathrm{R} 1$ and $\mathrm{R} 2$ were a few nanometers different from reported values [31], which may be due to some level of residual strain in the oxide scale [33]. The $\theta-\mathrm{Al}_{2} \mathrm{O}_{3}$ luminescence spectrum consisting of the T1-T2 doublet was detected at $685 \mathrm{~nm}$ and $687 \mathrm{~nm} . \mathrm{T} 1$ peaks were always detected while T2 peaks were detected intermittently, apparently when the oxide scale formed was thick enough to yield sufficient intensity of $\theta-\mathrm{Al}_{2} \mathrm{O}_{3}$-specific luminescence. The relative positions of the $\mathrm{T} 1$ and T2 peaks are in reasonable agreement with what has been reported in the literature for $\theta$ $\mathrm{Al}_{2} \mathrm{O}_{3}[32]$

After oxidation in air for one hour at $900^{\circ} \mathrm{C}$, the R1-R2 doublet was observed, indicating the formation of $\alpha-\mathrm{Al}_{2} \mathrm{O}_{3}$. The doublet was not distinct due to low yield, but the two peaks of $\alpha-\mathrm{Al}_{2} \mathrm{O}_{3}$ could be clearly identified. A broad $\theta$-specific T1 peak was observed at a wavelength of $685 \mathrm{~nm}$, indicating $\theta-\mathrm{Al}_{2} \mathrm{O}_{3}$ was also present. After 2 hours of exposure in air, the T1-T2 doublet of $\theta-\mathrm{Al}_{2} \mathrm{O}_{3}$ was clearly discernible. The T1-T2 peak intensities and areas were much larger than those of the R2 luminescence from the $\alpha$ $\mathrm{Al}_{2} \mathrm{O}_{3}$, which clearly shows that $\theta-\mathrm{Al}_{2} \mathrm{O}_{3}$ outgrows $\alpha-\mathrm{Al}_{2} \mathrm{O}_{3}$ by this two-hour stage of the scale evolution. After 5 hours of exposure in air, the intensities and peak areas of both the $\theta$-specific T1-T2 doublet and the $\alpha$-specific R1-R2 doublet were greater than what were observed after 2 hours. The T1-T2 peak intensities and areas were much larger than those of the R2 luminescence from the $\alpha-\mathrm{Al}_{2} \mathrm{O}_{3}$. After 10 and 20 hours of exposure, $\theta-\mathrm{Al}_{2} \mathrm{O}_{3}$ outgrows $\alpha-\mathrm{Al}_{2} \mathrm{O}_{3}$, as deduced from a comparison of the associated doublets. Thus, $\theta$ $\mathrm{Al}_{2} \mathrm{O}_{3}$ growth quickly dominates during oxidation in air at $900^{\circ} \mathrm{C}$.

For the case of oxidation in $\mathrm{O}_{2}+0.1 \% \mathrm{SO}_{2}$ at $900^{\circ} \mathrm{C}$, only the $\mathrm{R} 1-\mathrm{R} 2$ doublet was detected after one hour of exposure; there was no evidence of the $\theta$-specific T1-T2 
doublet. Such a result indicates that $\alpha-\mathrm{Al}_{2} \mathrm{O}_{3}$ growth predominated during the initial 1 hour of exposure. After 2 hours of exposure, a T1 peak with a very weak intensity became apparent, indicating the minor formation of $\theta-\mathrm{Al}_{2} \mathrm{O}_{3}$. The $\mathrm{R} 1-\mathrm{R} 2$ doublet increased in intensity and had a larger peak area than the T1 peak. When the exposure increased to 5, 10 and 20 hours, the luminescence spectra from both $\theta-\mathrm{Al}_{2} \mathrm{O}_{3}$ and $\alpha-\mathrm{Al}_{2} \mathrm{O}_{3}$ increased in intensity, but the $\alpha$-specific R1-R2 doublet remained dominant, indicating that the scale, compared to that formed in air, consisted of a larger amount of $\alpha-\mathrm{Al}_{2} \mathrm{O}_{3}$ during its entire early-stage growth period. In summary, during oxidation in $\mathrm{O}_{2}+0.1 \% \mathrm{SO}_{2}$, $\alpha-\mathrm{Al}_{2} \mathrm{O}_{3}$ was the more predominant oxide in the scale from the very early stages of oxidation when compared with exposure in air.

The relative amounts of $\alpha-\mathrm{Al}_{2} \mathrm{O}_{3}$ and $\theta-\mathrm{Al}_{2} \mathrm{O}_{3}$ were semi-quantitatively estimated by comparing the R1-R2 $(\alpha)$ and T1-T2 $(\theta)$ doublet intensities. The volume fraction of $\alpha$ $\mathrm{Al}_{2} \mathrm{O}_{3}$ after 1, 2, 5, 10 and 20 hours was estimated using the following approximation [34, 35].

$$
f_{\alpha}=\frac{A_{R 1}+A_{R 2}}{A_{R 1}+A_{R 2}+\psi\left(A_{T 1}+A_{T 2}\right)}
$$

where $\mathrm{A}$ is the integrated area underneath peak intensity of a given characteristic doublet. The constant $\psi$ is introduced to adjust for the relatively weaker luminescence from $\theta$ $\mathrm{Al}_{2} \mathrm{O}_{3}$. The value of $\psi$ was set as 12 , since a previous study reported $\theta-\mathrm{Al}_{2} \mathrm{O}_{3}$ luminescence can be 10-12 times weaker than $\alpha-\mathrm{Al}_{2} \mathrm{O}_{3}$ luminescence [33]. In this analysis, $\psi$ was assumed to be a constant, realizing that, in reality, it can vary due to dynamic effects. Although the real $\alpha-\mathrm{Al}_{2} \mathrm{O}_{3}$ volume fraction within the oxide scale may be different from the calculated value, the estimated trend in the variation in the $\alpha-\mathrm{Al}_{2} \mathrm{O}_{3}$ 
fraction should be reasonably represented, regardless of the $\psi$ value used. The results are plotted in Figure 4.

A larger percentage of $\alpha-\mathrm{Al}_{2} \mathrm{O}_{3}$ was observed after one hour of oxidation in both environments, indicating predominantly $\alpha-\mathrm{Al}_{2} \mathrm{O}_{3}$ growth during this very early stage of scale evolution. With increasing exposure time, the fraction of $\alpha-\mathrm{Al}_{2} \mathrm{O}_{3}$ first decreased at 2 hours and then increased at 5 hours. The extents of these changes depended on the atmosphere. Specifically, the volume fraction of $\alpha-\mathrm{Al}_{2} \mathrm{O}_{3}$ formed in the $\mathrm{SO}_{2}$-containing atmosphere is $\sim 43 \%$ greater than what formed in air after 5 hours. The fraction of $\alpha$ $\mathrm{Al}_{2} \mathrm{O}_{3}$ was very small during oxidation in air from 5 to 20 hours, increasing only slightly. By contrast, it is seen in Figure 4 that the comparatively higher fraction of $\alpha-\mathrm{Al}_{2} \mathrm{O}_{3}$ in the $\mathrm{O}_{2}+1 \% \mathrm{SO}_{2}$ atmosphere increased with exposure time, suggesting that there was a continual establishment of $\alpha-\mathrm{Al}_{2} \mathrm{O}_{3}$ during the scale growth during this period.

2. Sample condition before exposure to an $\mathrm{O}_{2}+0.1 \% \mathrm{SO}_{2}$ atmosphere at $900^{\circ} \mathrm{C}$

To understand the sulfur effect in promoting the $\alpha-\mathrm{Al}_{2} \mathrm{O}_{3}$ establishment, the sample surface condition immediately prior to high-temperature exposure to the $\mathrm{O}_{2}+0.1 \% \mathrm{SO}_{2}$ atmosphere was investigated. Based on the experimental procedure used, the samples sat outside the hot zone at around $150^{\circ} \mathrm{C}$ for at least 12 hours in an $\mathrm{O}_{2}+0.1 \%\left(\mathrm{SO}_{2}+\mathrm{SO}_{3}\right)$ environment prior to being inserted to the hot zone.

XPS was used to identify the chemical state of the sulfur enriched on the sample surface after the low temperature exposure and the resulting spectra are shown in Figure 5. The sample was exposed to $\mathrm{O}_{2}+0.1 \% \mathrm{SO}_{2}$ at $\sim 150^{\circ} \mathrm{C}$ for 12 hours. From the broad region scan (Figure 5a), main peaks are from $\mathrm{Ni}, \mathrm{O}$ and $\mathrm{S}$, with a very minor $\mathrm{Cr}$ peak. The Sp2 peak (Figure 5c) located at $168.9 \mathrm{eV}$ corresponds to sulfur in the $\mathrm{S}^{6+}$ state [36]. 
Figure 5 also shows the results from de-convoluting the spectrum to individual contributing peaks from $\mathrm{S}^{6+}$ and elemental sulfur. It was determined from this deconvolution that $98 \%$ of the sulfur exists in the $S^{6+}$ state. The main Ni $2 p^{3} / 2$ peak (Figure 5b) is located at $857 \mathrm{eV}$, which corresponds to $\mathrm{NiSO}_{4}$ [37-39]. As the sample contains $>70 \mathrm{at} . \% \mathrm{Ni}$ and the majority of cation spectra are from elemental $\mathrm{Ni}$, it was deduced that the surface-enriched sulfur exists primarily in the form $\mathrm{NiSO}_{4}$. Järdnäs et al. [40] similarly reported sulfate formation on the oxide surface of a 304L stainless steel exposed to $\mathrm{O}_{2}+40 \% \mathrm{H}_{2} \mathrm{O}+100 \mathrm{ppmSO}_{2}$ at $600^{\circ} \mathrm{C}$.

Cross-sectional TEM samples were prepared from this "pre-test" sample. Figure 6 is an HAADF-STEM image and corresponding EDS elemental maps of the surface of the alloy. The presence of two distinct layers was observed. The alloy surface layer was oxygen-rich with a total thickness of $\sim 90 \mathrm{~nm}$ (Figure $6 \mathrm{~b}$ ), while an outermost sulfur-rich layer $\sim 20 \mathrm{~nm}$ thick (Figure 6c) was also present. This sulfur-rich layer is in agreement with the XPS results, which identified sulfur-enrichment at the surface in the form of $\mathrm{NiSO}_{4}$. The formation of an outermost $\mathrm{NiSO}_{4}$ layer at the low temperature of $150^{\circ} \mathrm{C}$ was calculated to be thermodynamically stable, as will be discussed in the next sections. It should be noted that during STEM characterization, only certain areas were found to have a sulfur-rich surface layer. This may be attributed to the TEM sample preparation, wherein the $20 \mathrm{~nm}$ thin sulfur layer may have been removed from some regions during the ion milling step. It may also be due to the layer being discontinuous. Regardless of the continuity of this layer, it will be reasoned in the following sections that sulfur (in some form) was retained at the surface during subsequent sample heating and served to kinetically poison the oxidation processes. 
The chemical identities of the sulfur-rich and oxygen-rich layers detected by EDS (cf. Figure $6 \mathrm{~b}$ and $\mathrm{c}$ ) on the pre-test sample were further explored through analysis of the EELS O K edge signal. The presence of pre-peak $\alpha$ in the $\mathrm{O} \mathrm{K}$ edge from the O-rich layer spectrum in comparison to no pre-peak in the S-rich layer (cf. Figure S1 in the Supplemental Information section) indicated that the oxygen bonding is different in these two layers, possibly $\mathrm{NiO}$ and/or $\mathrm{Cr}_{2} \mathrm{O}_{3}$ versus sulfate. However, confirmation of the oxygen bonding within the oxygen-rich and sulfur-rich layers was not possible due to the lack of reference spectra to compare the $\mathrm{O} \mathrm{K}$ edges against for near-edge fine structure analysis, as is further discussed in the Supplemental Information section, S1.

3. Verification of the effect of surface-enriched sulfur

It is conjectured that the promoted $\alpha-\mathrm{Al}_{2} \mathrm{O}_{3}$ establishment is related to the surface enrichment of sulfur that occurred prior to high-temperature exposure. To test this, samples of the model alloy were given the pre-test exposure $\left(\mathrm{O}_{2}+0.1 \% \mathrm{SO}_{2}\right.$ at $\left.150^{\circ} \mathrm{C}\right)$ and then oxidized in air at $900^{\circ} \mathrm{C}$ for 10 and 20 hours. The specific testing procedure involved: (1) laying the sample in the pre-heat zone of the furnace (maximum temperature $150^{\circ} \mathrm{C}$ ) and exposing it to flowing Ar gas for two hours followed by $\mathrm{O}_{2}+0.1 \% \mathrm{SO}_{2}$ for 12 hours and then (2) removal of the sample from the pre-test position followed immediately by exposure to air at $900^{\circ} \mathrm{C}$ for 20 hours.

PSLS was conducted on the exposed surfaces and the resulting luminescence spectra are shown in Figure 7. The $\alpha$-specific R1-R2 doublet was detected with very strong intensity while the $\theta$-specific T1-T2 doublet intensity was weak. The fraction of $\alpha-$ $\mathrm{Al}_{2} \mathrm{O}_{3}$ was quantified to be around $50 \%$ at 10 hours when sulfur is enriched on the sample surface, even though the high-temperature exposure was done in air. The same alloy 
exposed directly to air and without exposing to the pre-test condition formed predominantly $\theta-\mathrm{Al}_{2} \mathrm{O}_{3}$. The volume fraction of $\alpha-\mathrm{Al}_{2} \mathrm{O}_{3}$ was estimated to be less than $4 \%$ within 20 hours (c.f. Figure 2 and Figure 4). Thus a small amount of sulfur on the alloy surface, present prior to high-temperature exposure, can promote $\alpha-\mathrm{Al}_{2} \mathrm{O}_{3}$ establishment.

\section{Discussion}

1. The kinetic competition of alpha and transient aluminas

A key finding in this study is that the presence of trace sulfur in the atmosphere can promote the establishment of $\alpha-\mathrm{Al}_{2} \mathrm{O}_{3}$. Such a finding has only been recently reported $[26,27]$. The nature of the $\theta \rightarrow \alpha$ transformation is diffusion controlled [11] and generally involves the heterogeneous nucleation of $\alpha-\mathrm{Al}_{2} \mathrm{O}_{3}$ followed by lateral growth and associated conversion of the initially-grown $\theta$ to $\alpha$. Nucleation is a thermally activated process [11], in which nuclei have to overcome a certain free energy barrier and elements migrate to nuclei by diffusion. Once $\alpha-\mathrm{Al}_{2} \mathrm{O}_{3}$ nucleates, it grows laterally more rapidly than vertically $[9,41-43]$, with the $\alpha-\mathrm{Al}_{2} \mathrm{O}_{3}$ nuclei eventually impinging and developing into a complete layer on the alloy. This layer significantly slows the outward flow of Al cations and thus stifles further $\theta$-phase growth [44].

The $\alpha-\mathrm{Al}_{2} \mathrm{O}_{3}$ nucleation rate and the relative growth rates of $\alpha-\mathrm{Al}_{2} \mathrm{O}_{3}$ and $\theta-\mathrm{Al}_{2} \mathrm{O}_{3}$ are important factors in determining their proportions in the initially-established oxide. The nucleation rate of $\alpha-\mathrm{Al}_{2} \mathrm{O}_{3}$ is important because a larger density of nuclei will make it easier for this stable oxide to coalesce and form a continuous layer. The growth rates of the different alumina phases are important because before $\alpha-\mathrm{Al}_{2} \mathrm{O}_{3}$ eventually establishes to a complete layer, there is a competitive growth of $\theta-\mathrm{Al}_{2} \mathrm{O}_{3}$ and $\alpha-\mathrm{Al}_{2} \mathrm{O}_{3}[42,45]$. This competitive growth can be particularly pronounced due to the significantly different 
growth rates of $\theta-\mathrm{Al}_{2} \mathrm{O}_{3}$ and $\alpha-\mathrm{Al}_{2} \mathrm{O}_{3}$. Usually at low temperature in air, the much faster growth of $\theta-\mathrm{Al}_{2} \mathrm{O}_{3}$ is favored to predominate initially, which in turn slows the rate of $\alpha$ $\mathrm{Al}_{2} \mathrm{O}_{3}$ to establish as a layer at the alloy/oxide interface. Based on this, any effects that change the relative growth rate of $\theta-\mathrm{Al}_{2} \mathrm{O}_{3}$ can affect its proportion in the scale. Stated differently, any effect that facilitates $\alpha-\mathrm{Al}_{2} \mathrm{O}_{3}$ nucleation and lateral growth would serve to promote its establishment.

The observations in this study clearly revealed the kinetic competition between $\theta$ $\mathrm{Al}_{2} \mathrm{O}_{3}$ and $\alpha-\mathrm{Al}_{2} \mathrm{O}_{3}$. As shown in Figure 2, the relative peak intensities of the $\theta$-specific T1-T2 doublet and the $\alpha$-specific R1-R2 doublet change in quite different manners as a function of oxidation time. In particular, there is a dramatic difference in the intensities when going from 1 hour to 2 hours of oxidation. These intensities reflect the relative amounts of $\theta$ - and $\alpha-\mathrm{Al}_{2} \mathrm{O}_{3}$ formed within the scale, which in turn can be ascribed to a kinetic competition between the metastable and stable polymorphs of alumina during the early stages of reaction. During early-stage oxidation in air, $\theta-\mathrm{Al}_{2} \mathrm{O}_{3}$ eventually overtakes the growth of $\alpha-\mathrm{Al}_{2} \mathrm{O}_{3}$ and is therefore the predominant phase (Figure 2), whereas, a larger percentage of $\alpha-\mathrm{Al}_{2} \mathrm{O}_{3}$ was formed (Figure 3) throughout all stages of oxidation in $\mathrm{O}_{2}+1 \% \mathrm{SO}_{2}$. Interestingly, $\alpha$ was apparently the predominant phase in the scale at the very early stage of reaction in both air and $\mathrm{O}_{2}+1 \% \mathrm{SO}_{2}$ (i.e., at one hour). Thus, sulfur clearly affected the kinetic competition between $\theta-\mathrm{Al}_{2} \mathrm{O}_{3}$ and $\alpha-\mathrm{Al}_{2} \mathrm{O}_{3}$ during scale establishment.

After 20 hours of oxidation in $\mathrm{O}_{2}+0.1 \% \mathrm{SO}_{2}$, the volume fraction of $\alpha-\mathrm{Al}_{2} \mathrm{O}_{3}$ was around $51 \%$ (Figure 4). Without cross-sectional TEM characterization of the formed oxide scale, accurate determination of the volumetric distribution of $\alpha-\mathrm{Al}_{2} \mathrm{O}_{3}$ is not 
possible. As reported elsewhere[46], kinetic measurement of the oxidation rate of the model alloy with pre-test exposure $\left(\mathrm{O}_{2}+0.1 \% \mathrm{SO}_{2}\right.$ at $\left.150^{\circ} \mathrm{C}\right)$ during oxidation in air at $900^{\circ} \mathrm{C}$ showed a progressive decrease in $\mathrm{k}_{\mathrm{p}}$ from $3.0 \times 10^{-13} \mathrm{~g}^{2} / \mathrm{cm}^{4} \mathrm{~s}$ at 2.5 hour to 1.6 $\mathrm{x} 10^{-13} \mathrm{~g}^{2} / \mathrm{cm}^{4} \mathrm{~s}$ at 20 hour. By contrast, the $\mathrm{k}_{\mathrm{p}}$ remained relatively constant at $3.5 \times 10^{-13}$ $\mathrm{g}^{2} / \mathrm{cm}^{4} \mathrm{~s}$ when the model alloy was directly oxidized in air at $900{ }^{\circ} \mathrm{C}$. These $\mathrm{k}_{\mathrm{p}}$ values compare well with reported rate constants for $\theta-\mathrm{Al}_{2} \mathrm{O}_{3}$ scale growth [7]. The gradual decrease in $k_{p}$ when sulfur is present is inferred to be due to sulfur promoting $\alpha-\mathrm{Al}_{2} \mathrm{O}_{3}$ establishment. Thus, given the measured kinetics, there is clearly a mixed mode of oxide growth during oxidation in $\mathrm{O}_{2}+0.1 \% \mathrm{SO}_{2}$, with the volume fraction of $\alpha-\mathrm{Al}_{2} \mathrm{O}_{3}$ steadily increasing.

The initial predominance of $\alpha-\mathrm{Al}_{2} \mathrm{O}_{3}$ was unexpected, given the widely reported results that the first-formed scale is usually comprised of metastable aluminas [41, 42], with stable $\alpha-\mathrm{Al}_{2} \mathrm{O}_{3}$ taking over at a later stage [42]. The underlying reason for this observed sequence is still not clear, but it is apparently not limited to a Ni-based system. A recent study by Chegroune et al. [45] on the Fe-based alloy "Aluchrom YHfAl" exposed for various times at $925^{\circ} \mathrm{C}$ in $\mathrm{Ar}+15 \% \mathrm{O}_{2}$ also showed an initial growth of $\alpha$ $\mathrm{Al}_{2} \mathrm{O}_{3}$, followed by transient alumina growth and later transformation back to $\alpha-\mathrm{Al}_{2} \mathrm{O}_{3}$. After 30 minutes of exposure, those authors could detect only $\alpha-\mathrm{Al}_{2} \mathrm{O}_{3}$ using glancingangle XRD. $\theta-\mathrm{Al}_{2} \mathrm{O}_{3}$ was detected later and its percentage increased with time up to a maximum at 14 hours, after which $\alpha-\mathrm{Al}_{2} \mathrm{O}_{3}$ again predominated.

2. The surface blocking effect induced by the surface enrichment of sulfur One key finding in this study is that a 20 nm-thick layer enriched with sulfur (Figure 6c) formed on the sample surface when exposed for 12 hours to $\mathrm{O}_{2}+0.1 \% \mathrm{SO}_{2}$ in 
the pre-test position $\left(\sim 150^{\circ} \mathrm{C}\right)$. Based on XPS analysis, which has a $\sim 10 \mathrm{~nm}$ depth of penetration limit[47], the sulfur was mainly in the form of $\mathrm{NiSO}_{4}$ (i.e. $\mathrm{S}^{6+}$ state) at least in large part if it is not exclusive. Another key finding is that $\sim 50 \%$ of $\alpha-\mathrm{Al}_{2} \mathrm{O}_{3}$ was formed during subsequent oxidation when sulfur is enriched on the sample surface, even though the high-temperature exposure was done in air (Figure 7). Thus, the low-temperature surface enrichment of sulfur can promote $\alpha-\mathrm{Al}_{2} \mathrm{O}_{3}$ establishment during subsequent thermal exposure. These findings are novel and a proposed mechanism is presented in the following.

To seek a mechanistic understanding of the observed sulfur effect, the formation path of $\mathrm{NiSO}_{4}$ at low temperature was analyzed. $\mathrm{NiSO}_{4}$ can be formed by the following reaction[48]:

$$
\mathrm{NiO}(\mathrm{s})+\mathrm{SO}_{3}(\mathrm{~g})=\mathrm{NiSO}_{4}(\mathrm{~s})
$$

Though $\mathrm{NiSO}_{4}$ had formed at the surface, an analysis based on bulk materials thermodynamics can still provide guidance on stabilities. As can be seen in the $\mathrm{NiO} / \mathrm{NiSO}_{4}$ stability diagram (Figure 8), reaction (1) is only stable to proceed to the right at temperatures below about $675^{\circ} \mathrm{C}$ in an equilibrated $\mathrm{O}_{2}+0.1 \% \mathrm{SO}_{2}$ atmosphere. Thus, the $\mathrm{NiSO}_{4}$ is stable to form at low temperature $\left(\sim 150^{\circ} \mathrm{C}\right)$ in the pre-test position but it is apt to dissociate during heating to $900^{\circ} \mathrm{C}$.

An important question would be: How is the alumina scale establishment affected at high temperature if $\mathrm{NiSO}_{4}$ dissociates? One possibility is that after $\mathrm{NiSO}_{4}$ dissociation, sulfur is still retained (i.e., chemisorbed) on the sample surface and has a poisoning effect on the subsequent oxidation reaction. It has been reported that sulfur can chemisorb on an alloy surface and block the surface sites required for the decomposition of the gas 
molecules responsible for corrosion $[49,50]$. Further, recent study on $9-12 \% \mathrm{Cr}$ steels by Quadakkers et al. [51] showed greater adsorbing strength of $\mathrm{SO}_{2}$ compared to $\mathrm{O}_{2}$. Thus, it is possible that once the available reactive adsorption sites are occupied by $\mathrm{SO}_{2}$ or sulfur in general, $\mathrm{O}_{2}$ adsorption, and hence oxidation reaction is impeded. Regardless of whether sulfur or a sulfur-containing species inhibits the $\mathrm{O}_{2}$ adsorption or the $\mathrm{O}_{2}$ decomposition on the sample surface, the oxygen supply for the scale growth will be effectively hindered. Accordingly, the following hypothesis is proposed to explain how sulfur promotes the $\alpha-\mathrm{Al}_{2} \mathrm{O}_{3}$ establishment: the enrichment of sulfur blocks surface sites for oxygen reaction, thus, effectively leading to a decreased oxygen supply to the extent that $\theta-\mathrm{Al}_{2} \mathrm{O}_{3}$ growth is hindered more than $\alpha-\mathrm{Al}_{2} \mathrm{O}_{3}$ growth, favoring establishment of the latter. It is assumed that such a process caused the experimental observation of sulfur apparently promoting the $\theta \rightarrow \alpha-\mathrm{Al}_{2} \mathrm{O}_{3}$ transformation. Regardless of the form of sulfur on the sample surface at high temperature, the sulfur-inhibited oxygen supply for oxidation will be generally referred to in this paper as a "the blocking effect" by surfaceenriched sulfur.

3. Evaluation of the surface blocking effect hypothesis

The hypothesis outlined in the previous section assumes that the blocking by sulfur at the surface results in an effective decrease in the oxygen supply such that the growth rates of $\theta-\mathrm{Al}_{2} \mathrm{O}_{3}$ and $\alpha-\mathrm{Al}_{2} \mathrm{O}_{3}$ are affected to different extents; that establishment of thermodynamically stable $\alpha-\mathrm{Al}_{2} \mathrm{O}_{3}$ becomes kinetically facilitated. To evaluate this hypothesis, the oxygen supply required for maximum $\theta-\mathrm{Al}_{2} \mathrm{O}_{3}$ and $\alpha-\mathrm{Al}_{2} \mathrm{O}_{3}$ parabolic growth rates shall be calculated. 
The instantaneous amount of oxygen needed to grow $\alpha$ - or $\theta-\mathrm{Al}_{2} \mathrm{O}_{3}$ at a maximum, diffusion-controlled rate is dictated by the oxidation kinetics. From the Arrhenius plots for $\mathrm{Al}_{2} \mathrm{O}_{3}$ scale growth [7], the $900^{\circ} \mathrm{C}$ parabolic rate constant is $2.2 \times 10^{-13} \mathrm{~g}^{2} / \mathrm{cm}^{4}=\mathrm{s}$ for $\theta$ $\mathrm{Al}_{2} \mathrm{O}_{3}$ scale and $6.8 \times 10^{-16} \mathrm{~g}^{2} / \mathrm{cm}^{4} \cdot \mathrm{s}$ for $\alpha-\mathrm{Al}_{2} \mathrm{O}_{3}$ scale. The oxygen supply needed for $\alpha$ or $\theta$ growth, $J_{o}$, is given by.

$$
J_{O}=\frac{d\left(\Delta m_{\mathrm{O}}\right)}{d t}=\frac{1}{2} \sqrt{\frac{k_{p}}{t}}
$$

where $k_{p}$ is the parabolic rate constant and $t$ is time. The calculated $J_{o}$ is plotted as a function of reaction time in Figure 9. The oxygen needed for $\theta$ growth is much more than that for $\alpha$ due to the three-orders of magnitude difference in the respective $k_{p}$ values. As time increases, the instantaneous growth rate decreases, and so the oxygen supply needed correspondingly decreases.

Based on a treatment of mass transfer in the viscous gas flow regime [52], which is presented in the Supplemental Materials section, S2, the oxygen supply in the air is calculated to be $J_{O, \text { air }}=3.1 \times 10^{-6}\left(\mathrm{~g} / \mathrm{cm}^{2} \mathrm{~s}\right)$, which is above the scale used in Figure 9. Thus, the amount of oxygen supply in air is abundantly sufficient for both $\theta$ and $\alpha$ $\mathrm{Al}_{2} \mathrm{O}_{3}$ to grow at their maximum parabolic rates. In such a case, the $\theta$ is able to kinetically displace, at least initially, the $\alpha-\mathrm{Al}_{2} \mathrm{O}_{3}$. When sulfur is present, it is postulated that there is a surface blocking effect that essentially reduces oxygen supply in $\mathrm{O}_{2}+0.1 \% \mathrm{SO}_{2}$. If the oxygen supply is decreased to the level indicated by the black arrow in Figure 9, there would not be enough oxygen for $\theta-\mathrm{Al}_{2} \mathrm{O}_{3}$ to grow at its maximum rate, but sufficient for the maximum growth rate of $\alpha-\mathrm{Al}_{2} \mathrm{O}_{3}$. In this case, $k_{p, \theta}$ would decrease 
relative to $k_{p, \alpha}$. When $\theta-\mathrm{Al}_{2} \mathrm{O}_{3}$ formation is significantly hindered, the stable $\alpha-\mathrm{Al}_{2} \mathrm{O}_{3}$ can more easily establish itself as a complete scale by having less kinetic competition.

To support this inference, samples of the model alloy were oxidized in $99.999 \%$ high-purity $\operatorname{Ar}\left(\mathrm{O}_{2}<1.4 \mathrm{ppm}\right)$. As outlined in the Supplemetal Materials section, S3, the oxygen supply in $\mathrm{Ar}$ is approximated to be $J_{O, A r}=4.6 \times 10^{-11} \mathrm{~g} / \mathrm{cm}^{2} \mathrm{~s}$. (assuming $\left.P_{O_{2}}=1.01 \times 10^{-6} \mathrm{~atm}\right)$. This $J_{O, A r}$ value is indicated by the dot dash line in Figure 9. The value is below that for un-inhibited $\theta$ growth, but close to the oxygen supply needed for $\alpha$ growth at its reported rate. Thus, if the hypothesis that limited oxygen supply favors $\alpha$ $\mathrm{Al}_{2} \mathrm{O}_{3}$ formation is valid, then one should expect to see the promoted establishment of $\alpha$ $\mathrm{Al}_{2} \mathrm{O}_{3}$ in Ar. Figure 10 shows PSLS spectra from the scales formed on model alloy during isothermal oxidation in $\mathrm{Ar}$ at $900^{\circ} \mathrm{C}$. Very strong $\alpha-\mathrm{Al}_{2} \mathrm{O}_{3}$ peaks were clearly observed after 10 and 20 hours of oxidation. The $\alpha-\mathrm{Al}_{2} \mathrm{O}_{3}$ fraction was estimated to be $51 \%$ after 20 hours of oxidation in high-purity Ar. The same alloy, when oxidized in air for 10 and 20 hours, formed primarily $\theta-\mathrm{Al}_{2} \mathrm{O}_{3}\left(\alpha-\mathrm{Al}_{2} \mathrm{O}_{3}\right.$ fraction was estimated to less than $4 \%$ within 20 hours), as shown in Figure 2 and 4. Thus, the establishment of $\alpha-\mathrm{Al}_{2} \mathrm{O}_{3}$ was favored when exposure was done in high-purity Ar. In other words, low $P_{O_{2}}$ or, in turn, low $J_{o}$, favors $\alpha-\mathrm{Al}_{2} \mathrm{O}_{3}$ establishment. A similar result was observed on an EBPVD NiCoCrAlY coating during oxidation at $1100^{\circ} \mathrm{C}[53,54]$. Specifically, it was found in those studies that after 1 hour oxidation in $0.1 \mathrm{~Pa}$ oxygen atmosphere, an exclusive $\alpha$ $\mathrm{Al}_{2} \mathrm{O}_{3}$ scale was formed; whereas $\theta-\mathrm{Al}_{2} \mathrm{O}_{3}$ scale formed when oxidized at $100 \mathrm{~Pa}$ oxygen.

For a complete analysis of the $\alpha-\mathrm{Al}_{2} \mathrm{O}_{3}$ establishment, nucleation rates must also be considered. For heterogeneous nucleation, there is a substrate structure effect such that any orientation that provides compatibility with $\alpha-\mathrm{Al}_{2} \mathrm{O}_{3}$ will facilitate its nucleation [55- 
57]. The same is true for $\theta-\mathrm{Al}_{2} \mathrm{O}_{3}$. For example, due to an epitaxial orientation relationship between $\beta-\mathrm{NiAl}$ and $\theta-\mathrm{Al}_{2} \mathrm{O}_{3}, \beta-\mathrm{NiAl}$ substrate prefers $\theta-\mathrm{Al}_{2} \mathrm{O}_{3}$ nucleation [14, 58, 59]. For $\beta$-NiAl, low $P_{O_{2}}$ might not necessarily promote $\alpha-\mathrm{Al}_{2} \mathrm{O}_{3}$ scale establishment. However, in this study, the alloy substrate is $\gamma^{\prime}-\mathrm{Ni}_{3} \mathrm{Al}$ and there is no known orientation preference for either $\theta-\mathrm{Al}_{2} \mathrm{O}_{3}$ or $\alpha-\mathrm{Al}_{2} \mathrm{O}_{3}$ nucleation. Thus, it is inferred that the significantly reduced growth rate of $\theta-\mathrm{Al}_{2} \mathrm{O}_{3}$ relative to that of $\alpha-\mathrm{Al}_{2} \mathrm{O}_{3}$ in a low $P_{O_{2}}$ environment promotes $\alpha-\mathrm{Al}_{2} \mathrm{O}_{3}$ scale establishment on $\gamma^{\prime}-\mathrm{Ni}_{3} \mathrm{Al}$.

\section{Conclusions}

$\mathrm{A} \gamma^{\prime}-\mathrm{Ni}_{3} \mathrm{Al}$-based metal alloy was oxidized at $900^{\circ} \mathrm{C}$ in air and $\mathrm{O}_{2}+0.1 \% \mathrm{SO}_{2}$ for 1 , 2, 5, 10 and 20 hours. A kinetic competition between $\theta-\mathrm{Al}_{2} \mathrm{O}_{3}$ and $\alpha-\mathrm{Al}_{2} \mathrm{O}_{3}$ was observed during the scale growth. $\theta-\mathrm{Al}_{2} \mathrm{O}_{3}$ predominates during oxidation in air after a short time, while a comparatively larger percentage of stable $\alpha-\mathrm{Al}_{2} \mathrm{O}_{3}$ formed throughout all stages of oxidation in $\mathrm{O}_{2}+0.1 \% \mathrm{SO}_{2}$. Thus, the presence of sulfur is inferred to affect this kinetic competition of $\theta-\mathrm{Al}_{2} \mathrm{O}_{3}$ and $\alpha-\mathrm{Al}_{2} \mathrm{O}_{3}$ in such a way that $\alpha-\mathrm{Al}_{2} \mathrm{O}_{3}$ establishment is promoted.

The observed promotion of $\alpha-\mathrm{Al}_{2} \mathrm{O}_{3}$ establishment in the $\mathrm{SO}_{2}$-bearing atmosphere was due to sulfur enrichment on the alloy surface. The enrichment occurred when samples were exposed to $\mathrm{O}_{2}+1 \% \mathrm{SO}_{2}$ in the pre-tested position $\left(\sim 150^{\circ} \mathrm{C}\right)$, outside the hot zone. It was found by XPS measurement that the sulfur was mainly in the $\mathrm{S}^{6+}$ state, which was deduced to be associated with $\mathrm{NiSO}_{4}$. Cross-sectional STEM in conjunction with EDS confirmed a $\sim 20 \mathrm{~nm}$ sulfur-rich outermost layer and a $\sim 90 \mathrm{~nm}$ oxygen-rich inner layer, thus providing direct evidence of sulfur enrichment at the alloy surface. At elevated temperature, this $\mathrm{NiSO}_{4}$ is apt to dissociate, but sulfur is inferred to still be 
retained on surface. The surface enrichment of sulfur, whether continuous or not, was deduced to block the surface sites for oxygen reaction and consequently have the effect of decreasing oxygen supply for the scale growth. It is assumed that with limited oxygen supply, the faster growing $\theta-\mathrm{Al}_{2} \mathrm{O}_{3}$ is less favored, thus facilitating $\alpha-\mathrm{Al}_{2} \mathrm{O}_{3}$ establishment to a continuous layer during its kinetic competition with $\theta-\mathrm{Al}_{2} \mathrm{O}_{3}$. This hypothesis was supported by kinetic calculations and complementary tests in a low $\mathrm{p}_{\mathrm{O}_{2}}$ atmosphere. The establishment of an $\alpha-\mathrm{Al}_{2} \mathrm{O}_{3}$ scale was promoted on a model NiCrAlY alloy when oxidation took place in high purity $\operatorname{Ar}\left(\mathrm{O}_{2}<1.4 \mathrm{ppm}\right)$ at $900^{\circ} \mathrm{C}$. When oxygen supply is limited, the lateral growth rate of $\theta-\mathrm{Al}_{2} \mathrm{O}_{3}$ decreases more dramatically than that of $\alpha$ $\mathrm{Al}_{2} \mathrm{O}_{3}$. This inhibition of $\theta-\mathrm{Al}_{2} \mathrm{O}_{3}$ growth will allow $\alpha-\mathrm{Al}_{2} \mathrm{O}_{3}$ to gain advantage in establishing a continuous layer underneath. Therefore, the sulfur-promoted $\alpha-\mathrm{Al}_{2} \mathrm{O}_{3}$ establishment is due to sulfur preferentially adsorbing, acting as an $\mathrm{O}_{2}$ adsorption poison, and effectively limiting the supply of oxygen.

\section{Acknowledgements}


This research was mainly supported by the US Office of Naval Research, award N000014-09-1-1127 and managed by Dr. David Shifler. The authors thank Dr. Juan Manuel Alvarado-Orozco and Dr. Stephen House for helpful discussion, Dr. Karen Bustillo for the technical assistance on the microscopes and Marissa Mancuso for the TEM sample preparation. A part of this research was performed at the National Center for Electron Microscopy, Molecular Foundry, Lawrence Berkeley National Laboratory, which is supported by the Office of Science, Office of Basic Energy Sciences (BES), of the U.S. Department of Energy (DOE) under Contract No. DE-AC02-05CH11231. CSB and JCY acknowledge funding through DOE BES Catalysis Science under Contract No.DE-FG02-03ER15476.

\section{References}

[1] R. Sokhi. World Atlas of Atmospheric Pollution, Anthem Press, New York, 2008. [2] Z.H. Tang, B. Gleeson. Comparison of Air Quality Among USA, China, India and Middle East. 2012.

[3] F. Pettit. Hot corrosion of metals and alloys, Oxid Met 76 (2011) 1-21.

[4] X.Liu. Ph.D. Thesis. Effects of trace $\mathrm{SO}_{2}$ and $\mathrm{Na}_{2} \mathrm{SO}_{4}$ deposit on the reaction behavior of $\mathrm{Al}_{2} \mathrm{O}_{3}$-scale forming alloys. The University of Pittsburgh, 2014. p.174-199. [5] K. Wefers, C. Misra. Alcoa Technical Paper No. 19, Alcoa Laboratories, Pittsburgh, PA (1987).

[6] D. Lipkin, D. Clarke, M. Hollatz, M. Bobeth, W. Pompe. Stress development in alumina scales formed upon oxidation of (111) NiAl single crystals, Corrosion Science 39 (1997) 231-242.

[7] M. Brumm, H. Grabke. The oxidation behaviour of NiAl-I. Phase transformations in the alumina scale during oxidation of $\mathrm{NiAl}$ and $\mathrm{NiAl}-\mathrm{Cr}$ alloys, Corrosion Science 33 (1992) 1677-1690.

[8] G.C. Rybicki, J.L. Smialek. Effect of the $\Theta-\alpha-\mathrm{Al}_{2} \mathrm{O}_{3}$ transformation on the oxidation behavior of $\beta-\mathrm{NiAl}+\mathrm{Zr}$, Oxid Met 31 (1989) 275-304.

[9] V.K. Tolpygo, D.R. Clarke. Microstructural study of the theta-alpha transformation in alumina scales formed on nickel-aluminides. The 4th international conference on the Microscopy of Oxidation, vol. 17. Trinity Hall, Cambridge, 1999. p.59-70.

[10] J. Doychak, J.L. Smialek, C.A. Barrett. The oxidation of Ni-rich Ni-Al intermetallics, NASA Technical Reports Server (NTRS) (1988) 1-15. 
[11] R.B. Bagwell, G.L. Messing, P.R. Howell. The formation of $\alpha-\mathrm{Al}_{2} \mathrm{O}_{3}$ from $\mathrm{O}$ $\mathrm{Al}_{2} \mathrm{O}_{3}$ : The relevance of a "critical size" and: Diffusional nucleation or "synchro-shear"?, Journal of Materials Science 36 (2001) 1833-1841.

[12] B. Pint, M. Treska, L. Hobbs. The effect of various oxide dispersions on the phase composition and morphology of $\mathrm{Al}_{2} \mathrm{O}_{3}$ scales grown on $\beta$-NiAl, Oxid Met 47 (1997) 120.

[13] X.F. Zhang, K. Thaidigsmann, J. Ager, P.Y. Hou. Alumina scale development on iron alumindes, Journal of Materials Research 21 (2006) 1409-1419.

[14] J. Doychak, M. Rühle. TEM studies of oxidized $\mathrm{NiAl}$ and $\mathrm{Ni}_{3} \mathrm{Al}$ cross sections, Oxid Met 31 (1989) 431-452.

[15] B. Gleeson, Z.H.Tang. presented results. MS\&T conference. Pittsburgh, 2009.

[16] Y. Cadoret, M.P. Bacos, P. Josso, V. Maurice, P. Marcus, S. Zanna. Materials Science Forum 247 (2004) 461-464.

[17] Y. Cadoret, D. Monceau, M.P. Bacos, P. Josso, V. Maurice, P. Marcus. Effect of platinum on the growth rate of the oxide scale formed on cast nickel aluminide intermetallic alloys, Oxid Met 64 (2005) 185-205.

[18] K.M.N. Prasanna, A.S. Khanna, R. Chandra, W.J. Quadakkers. Effect of $\theta$ alumina formation on the growth kinetics of alumina-forming superalloys, Oxid Met 46 (1996) 465-480.

[19] H.J. Grabke. Materials Science Forum (1997) 251-254.

[20] J. Jedliński, S. Mrowec. The influence of implanted yttrium on the oxidation behaviour of $\beta$-NiAl, Materials Science and Engineering 87 (1987) 281-287.

[21] B. Pint, J. Martin, L. Hobbs. The oxidation mechanism of $\theta-\mathrm{Al}_{2} \mathrm{O}_{3}$ scales, Solid State Ionics 78 (1995) 99-107.

[22] Z.H. Zhou, H.B. Guo, M. Abbas, S.K. Gong. Corrosion Science 53 (2011) 29432947.

[23] S. Chevalier, P. Juzon, K. Przybylski, J.P. Larpin. Water vapor effect on hightemperature oxidation behavior of $\mathrm{Fe}_{3} \mathrm{Al}$ intermetallics, Science and Technology of Advanced Materials 10 (2009) 045006.

[24] F. Liu, H. Liu, H. Josefsson, J.E. Svensson, L.G. Johansson, M. Halvarsson. TEM investigation of the oxide scales formed on a FeCrAlRE alloy (Kanthal AF) at 900C in dry $\mathrm{O}_{2}$ and $\mathrm{O}_{2}$ with $40 \mathrm{H}_{2} \mathrm{O}$, Materials at High Temperatures 3 (2005) 521-526.

[25] H. Götlind, F. Liu, J.E. Svensson, M. Halvarsson, L.G. Johansson. The effect of water vapor on the initial stages of oxidation of the $\mathrm{FeCrAl}$ alloy kanthal $\mathrm{AF}$ at $900{ }^{\circ} \mathrm{C}$, Oxid Met 67 (2007) 251-266.

[26] X. Liu, B. Gleeson. The effect of environmental sulfur on the establishment and structural stability of alumina scales, Oxid Met 80 (2013) 517-527.

[27] M.N. Task. Ph.D. Thesis. Assessment of the factors affecting protective alumina formation under hot corrosion conditions. The University of Pittsburgh, 2012. p.193-199. [28] Materials Preparation Center, Ames Laboratory of US DOE, Ames, IA, USA, http://www.mpc.ameslab.gov.

[29] HSC Chemistry 7.

[30] D.B. Hovis, A.H. Heuer. The use of laser scanning confocal microscopy (LSCM) in materials science, Journal of Microscopy 240 (2010) 173-180. 
[31] J. He, D.R. Clarke. Determination of the piezospectroscopic coefficients for chromium-doped sapphire, Journal of the American Ceramic Society 78 (1995) 13471353.

[32] Q.Z. Wen, D.M. Lipkin, D.R.Clarke. Luminescence characterization of chromium-containing $\theta$-alumina, Journal of the American Ceramic Society 81 (1998) 3345-3348.

[33] V.K.Tolpygo, D.R. Clarke. Microstructural study of the theta-alpha transformation in alumina scales formed on nickel-aluminides. Microscopy of oxidation: proceedings of the fourth international conference on the microscopy of oxidation, vol. 17. Trinity Hall, Cambridge, UK: Science Reviews, 1999. p. 59-70.

[34] J.M. Alvarado-Orozco. Ph.D. Thesis. Kinetics study and characterization of thermally grown oxide on commercial $\beta$-(Ni,Pt)Al bond coats used in thermal barrier coating systems for gas turbine engine applications. Santiago de Querétaro, Qro. Mexico: Cinvestav, 2013. p.77.

[35] J.M. Alvarado-Orozco, R. Morales-Estrella, M.S. Boldrick, J.L. Ortiz-Merino, D.G. Konitzer, G. Trápaga-Martínez, J. Muñoz-Saldaña. First stages of oxidation of Ptmodified nickel aluminide bond coat systems at low oxygen partial pressure, Oxid Met 78 (2012) 269-284.

[36] B. Lindberg, K. Hamrin, G. Johansson, U. Gelius, A. Fahlman, C. Nordling, K. Siegbahn. Molecular spectroscopy by means of ESCA II. sulfur compounds. correlation of electron binding energy with structure, Physica Scripta 1 (1970) 286-298.

[37] F. Jin, H. Long, W. Song, G. Xiong, X. Guo, X. Wang. Active phase of a $\mathrm{NiSO}_{4}$ catalyst supported on $\gamma-\mathrm{Al}_{2} \mathrm{O}_{3}$ during in-situ self-sulfidation for selective hydrodesulfurization, Energy \& Fuels (2013).

[38] R.B. Shalvoy, P.J. Reucroft. Journal of Vacuum Science and Technology 16 (1979) 567-569.

[39] D.L. Legrand, H.W. Nesbitt, G.M. Bancroft. X-ray photoelectron spectroscopic study of a pristine millerite (NiS) surface and the effect of air and water oxidation, American Mineralogist 83 (1998) 1256-1265.

[40] A. Järdnäs, J.-E. Svensson, L.-G. Johansson. Influence of $\mathrm{SO}_{2}$ on the oxidation of 304L steel in $\mathrm{O}_{2}+40 \% \mathrm{H}_{2} \mathrm{O}$ at $600^{\circ} \mathrm{C}$, Oxid Met 69 (2008) 249-263.

[41] P.Y. Hou. Segregation phenomena at thermally grown $\mathrm{Al}_{2} \mathrm{O}_{3}$ /alloy interfaces, Annual Review of Materials Research 38 (2008) 275-298.

[42] B. W. Veal, A. P. Paulikas, R.C. Birtcher. Mechanisms and control of phase transition in thermally grown aluminas, Applied Physics Letters 89 (2006) 161916.

[43] P.Y. Hou, A. Paulikas, B. Veal. Growth strains and stress relaxation in alumina scales during high temperature oxidation. Materials Science Forum, vol. 461: Trans Tech Publ, 2004. p.671-680.

[44] E. Schumann. The effect of Y-ion implantation on the oxidation of $\beta$-NiAl, Oxid Met 43 (1995) 157-172.

[45] R. Chegroune, E. Salhi, A. Crisci, Y. Wouters, A. Galerie. On the competitive growth of alpha and transient aluminas during the first stages of thermal oxidation of FeCrAl Alloys at intermediate temperatures, Oxid Met 70 (2008) 331-337.

[46] X. Liu. B. Gleeson. To be published results. 2014.

[47] J.M. Wagner. X-ray photoelectron spectroscopy: chemical engineering methods and technology, Nova Science Publishers, Inc., 2013. 
[48] K.P. Lillerud, B. Haflan, P. Kofstad. On the reaction mechanism of nickel with $\mathrm{SO}_{2}+\mathrm{O}_{2} / \mathrm{SO}_{3}$, Oxid Met 21 (1984) 119-134.

[49] G. Luckman, R.S. Polizzotti. An effect of chemisorbing surface reaction poisons on the transition from internal to external oxidation, Metallurgical and Materials Transactions A 16 (1985) 133-136.

[50] H.J. Grabke, R. Möller, A. Schnaas. Werkst. Korros. 30 (1979) 794-799.

[51] W.J. Quadakkers. Private communication. 2013.

[52] R.B. Bird, W.E. Stewart, E.N. Lightfoot. Transport phenomena, Wiley, 2006.

[53] T.J. Nijdam, G.H. Marijnissen, E. Vergeldt, A.B. Kloosterman, W.G. Sloof.

Development of a pre-oxidation treatment to improve the adhesion between thermal barrier coatings and NiCoCrAlY bond coatings, Oxid Met 66 (2006) 269-294.

[54] T.J. Nijdam, L.P.H. Jeurgens, W.G. Sloof. Promoting exclusive $\alpha-\mathrm{Al}_{2} \mathrm{O}_{3}$ growth upon high-temperature oxidation of $\mathrm{NiCrAl}$ alloys: experiment versus model predictions, Acta Materialia 53 (2005) 1643-1653.

[55] J. Wynnyckyj, C. Morris. A shear-type allotropie transformation in alumina, Metallurgical and Materials Transactions B 16 (1985) 345-353.

[56] Z. Nishiyama, M.E. Fine, M. Meshii, C.M. Wayman. Martensitic transformation, Academic Press, 1978.

[57] M. Kumagai, G.L. Messing. Controlled transformation and sintering of a boehmite Sol-Gel by $\alpha$-Alumina seeding Journal of the American Ceramic Society 68 (1985) 500-505.

[58] J. Doychak, J.L. Smialek, T.E. Mitchell. Transient oxidation of single-crystal $\beta$ NiAl, MTA 20 (1989) 499-518.

[59] H.J.Grabke. Intermetallics 7 (1999) 1153-1158.

[60] D.B. Williams, C.B. Carter. Transmission Electron Microscopy: A textbook for Materials Science. Spectrometry. IV, Springer, 1996.

[61] C. Mitterbauer, G. Kothleitner, W. Grogger, H. Zandbergen, B. Freitag, P. Tiemeijer, F. Hofer. Electron energy-loss near-edge structures of 3d transition metal oxides recorded at high-energy resolution, Ultramicroscopy 96 (2003) 469-480.

[62] L.A. Grunes, R.D. Leapman, C.N. Wilker, R. Hoffmann, A.B. Kunz. Oxygen K near-edge fine structure: An electron-energy-loss investigation with comparisons to new theory for selected 3d transition-metal oxides, Physical Review B 25 (1982) 7157-7173. [63] D.R. Poirier, G.H. Geiger. Transport phenomena in materials processing, Minerals, Metals \& Materials Society, 1994.

[64] D.R. Gaskell. An introduction to transport phenomena in materials engineering, Prentice Hall, 1992.

[65] R.C. Reid, J.M. Prausnitz, B.E. Poling. The properties of gases and liquids, 1987.

[66] J.O. Hischfelder, R.B. Bird, E.L. Spotz. Chemical Reviews 44 (1949) 205.

[67] M. Næss, D.J. Young, J. Zhang, J. Olsen, G. Tranell. Active oxidation of liquid silicon: experimental investigation of kinetics, Oxid Met 78 (2012) 363-376. 


\section{Figures}

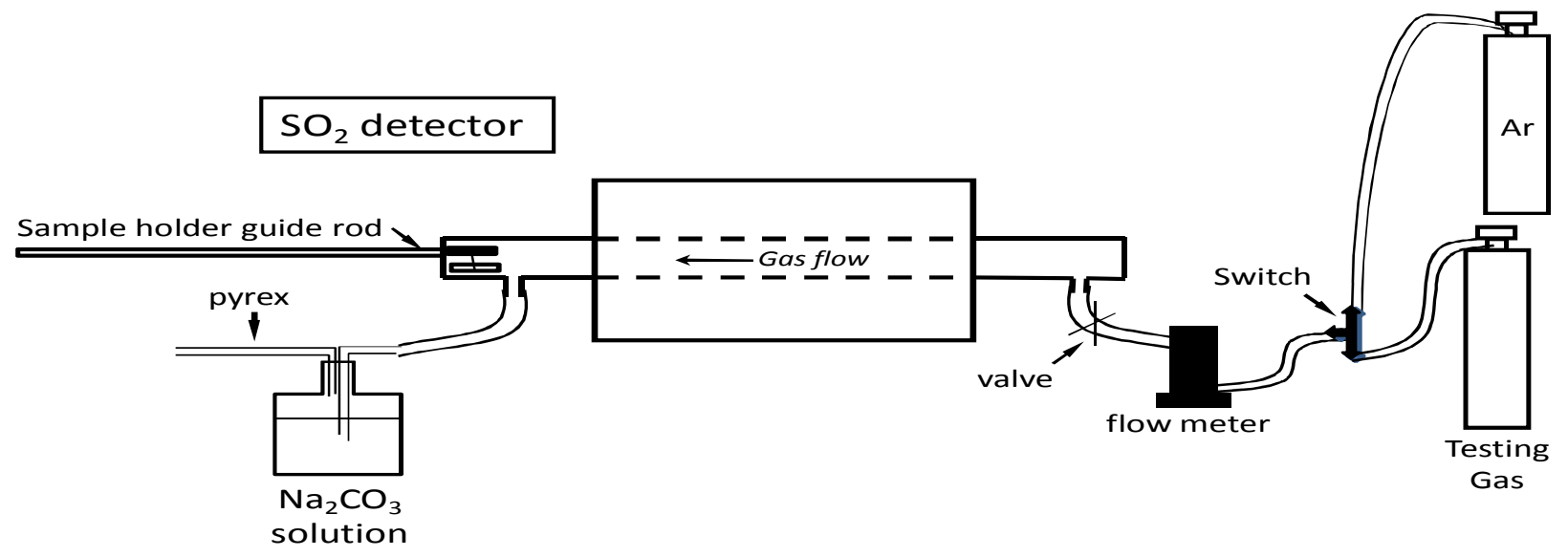

Figure 1 Sulfidation apparatus setup
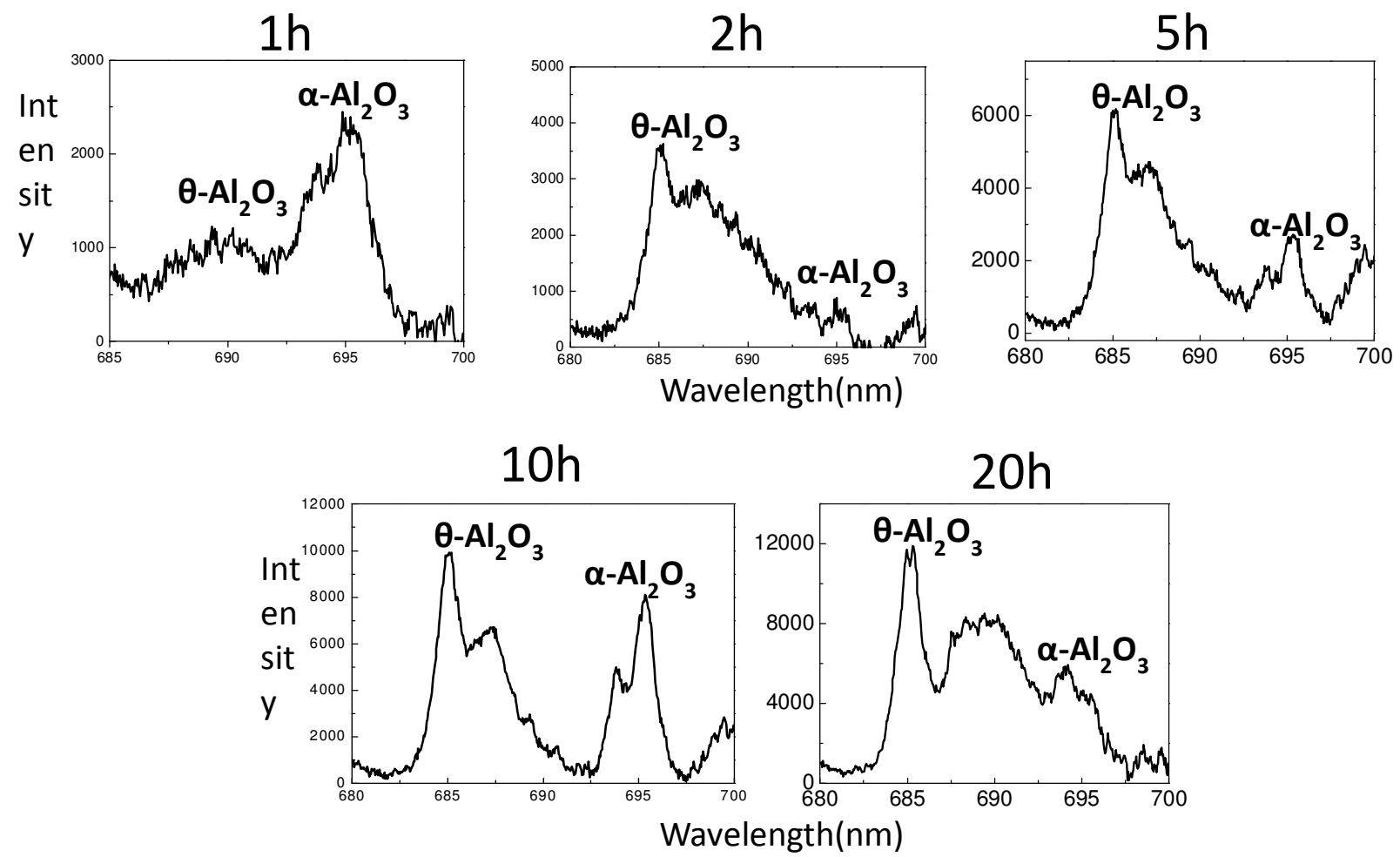

Figure 2 PSLS spectra from the scales formed on model alloy during isothermal oxidation in air at $900^{\circ} \mathrm{C}$ for various times (the characteristic spectrum of $\alpha-\mathrm{Al}_{2} \mathrm{O}_{3}$ is $\mathrm{R} 1$ -

$\mathrm{R} 2$ doublet, the characteristic spectrum of $\theta-\mathrm{Al}_{2} \mathrm{O}_{3}$ is $\mathrm{T} 1-\mathrm{T} 2$ 
doublet)
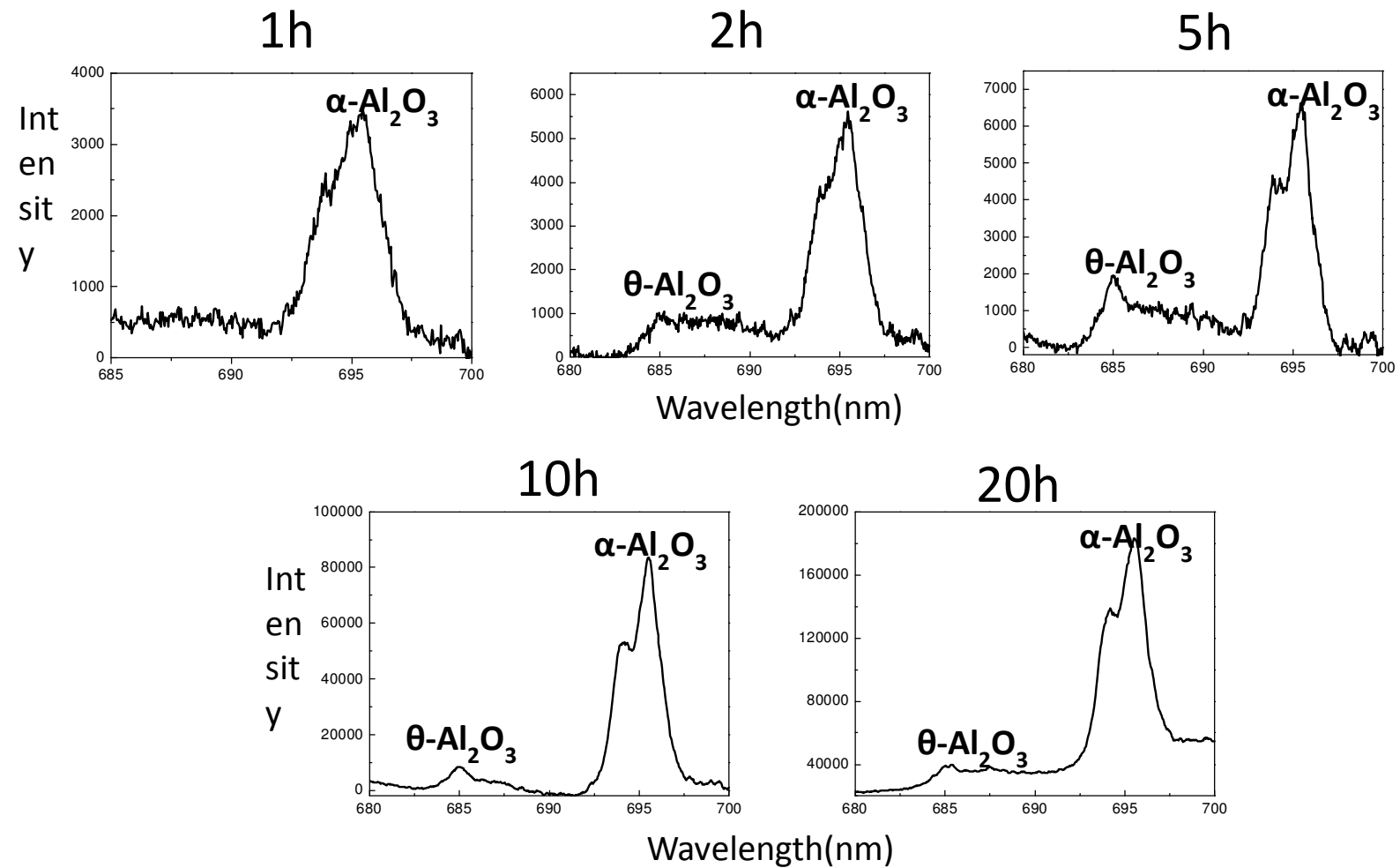

Figure 3 PSLS spectra from the scales formed on model alloy during isothermal oxidation in $\mathrm{O}_{2}+0.1 \% \mathrm{SO}_{2}$ at $900^{\circ} \mathrm{C}$ for various times 


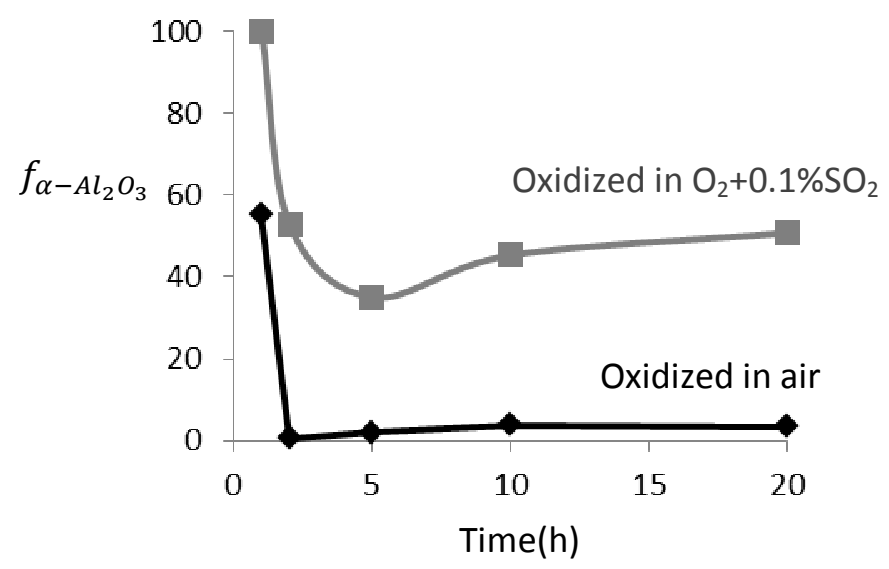

Figure 4 Estimated volume fraction of $\alpha-\mathrm{Al}_{2} \mathrm{O}_{3}$ within the oxide scale formed on model alloy exposed to air and $\mathrm{O}_{2}+0.1 \% \mathrm{SO}_{2}$ at $900^{\circ} \mathrm{C}$ for $1,2,5,10$ and 20 hours. 

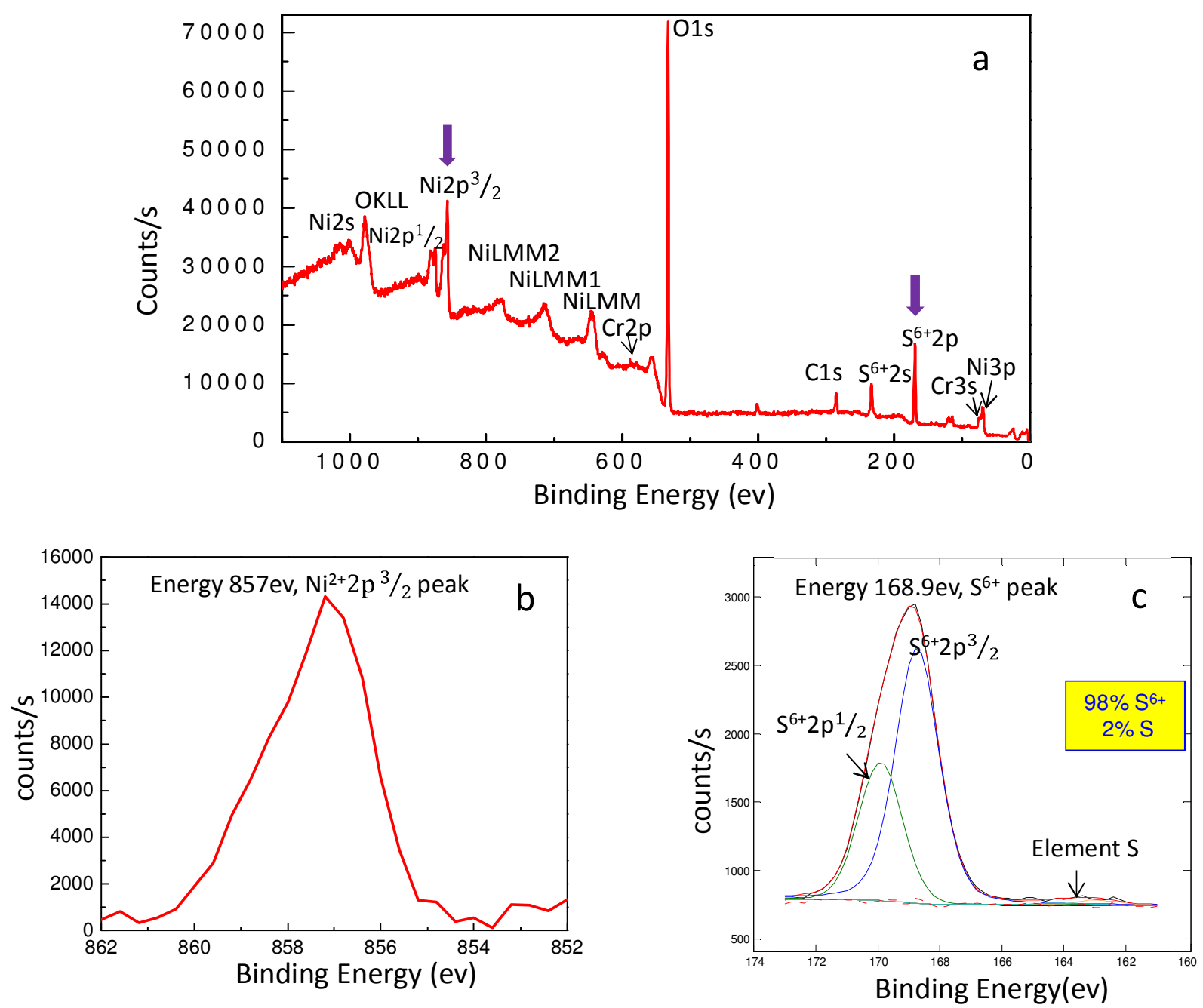

Figure 5 XPS binding-energy spectra on model alloy exposed to $\mathrm{O}_{2}+0.1 \% \mathrm{SO}_{2}$ at pre-test position $\left(\sim 150^{\circ} \mathrm{C}\right)$ for 12 hours (a) broad region, (b) $\mathrm{Ni}^{2+} 2 \mathrm{p}^{3} / 2$ region, (c) deconvolved spectra in the $S^{6+} 2 p$ region 

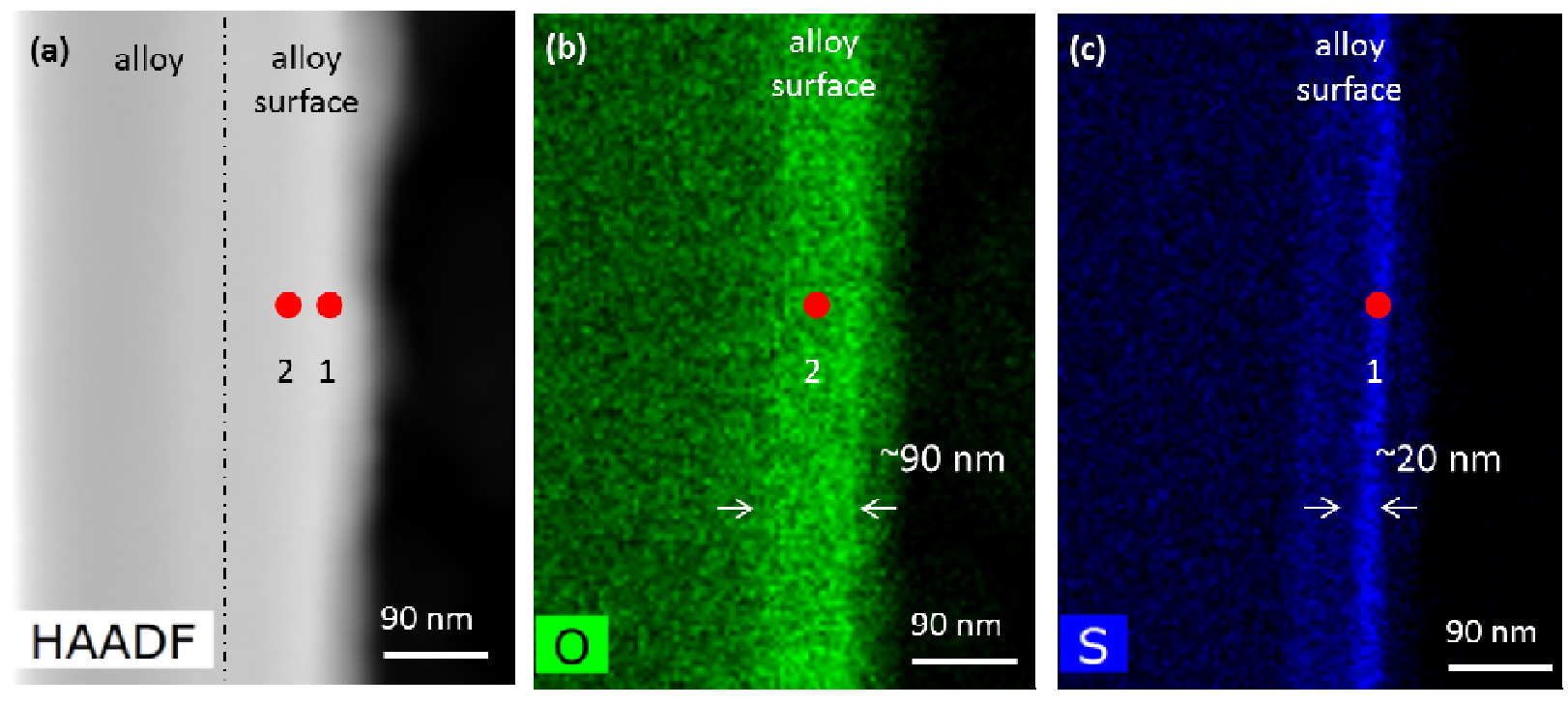

Figure 6 Cross-sectional STEM images from the alloy sample exposed to $\mathrm{O}_{2}+0.1 \% \mathrm{SO}_{2}$ at $\sim 150^{\circ} \mathrm{C}$ for 12 hours, with the alloy and alloy surface layers identified in the HAADF image (a). EDS elemental maps for oxygen (b) and sulfur (c), simultaneously acquired using the ChemiSTEM ${ }^{\mathrm{TM}}$ system, show the alloy surface to be composed of a $90 \mathrm{~nm}$ Orich layer with the top-most $20 \mathrm{~nm}$ layer being S-rich. The circles 1 and 2 correspond to where EEL spectra were acquired from the S-rich and O-rich regions, respectively (See supplemental information, S1).

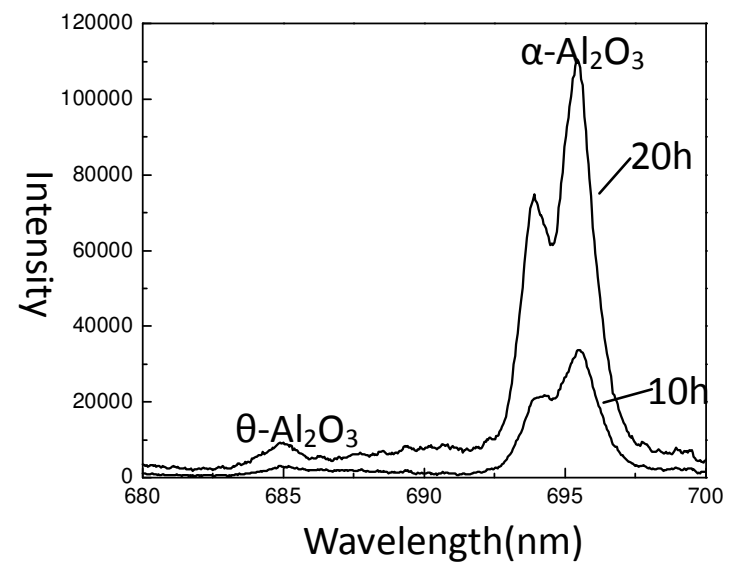


Figure 7 PSLS spectrum from the scales formed on model alloy during isothermal oxidation in air at $900^{\circ} \mathrm{C}$ after $150^{\circ} \mathrm{C}$ pre-exposure to $\mathrm{O}_{2}+0.1 \%\left(\mathrm{SO}_{2}+\mathrm{SO}_{3}\right)$

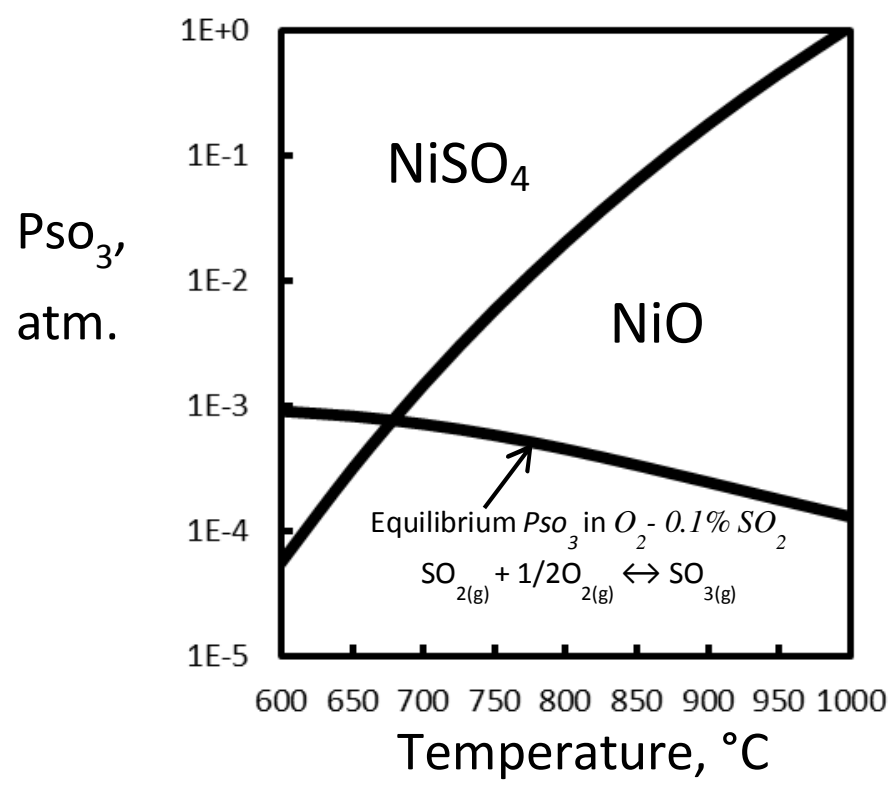

Figure 8 Stability diagrams of $\mathrm{NiO}$ and $\mathrm{NiSO}_{4}$

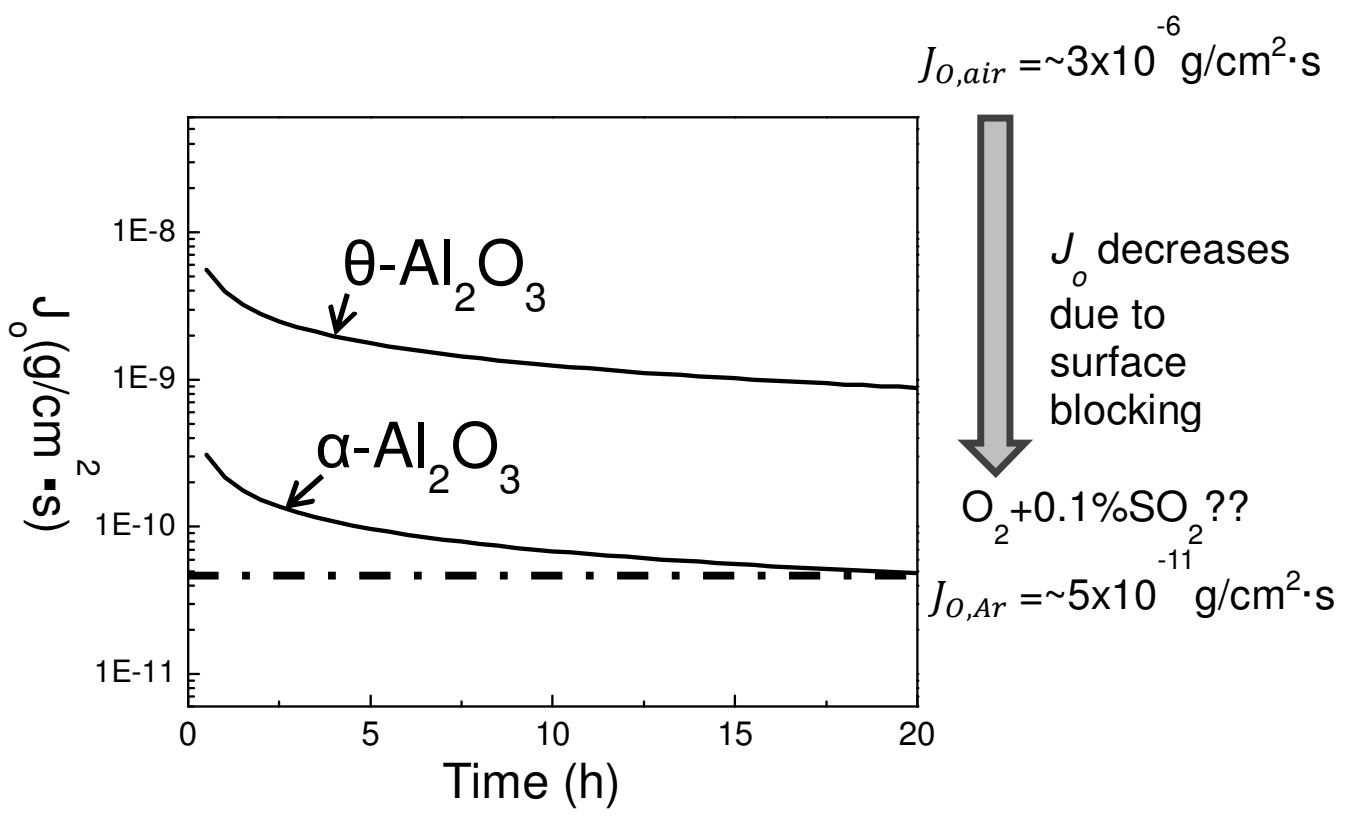


Figure 9 Comparison of $J_{o}$ vs. $t$ curves for $\alpha-\mathrm{Al}_{2} \mathrm{O}_{3}$ and $\Theta-\mathrm{Al}_{2} \mathrm{O}_{3}$ growth at $900^{\circ} \mathrm{C}$. The oxygen supply available in the air at $900^{\circ} \mathrm{C}$ and the proposed decreased oxygen supply in $\mathrm{O}_{2}+0.1 \% \mathrm{SO}_{2}$ atmosphere due to surface blocking effect (schematically shown by grey arrow). The oxygen supply available in $99.999 \%$ high purity Ar (represented by the dashdot line)

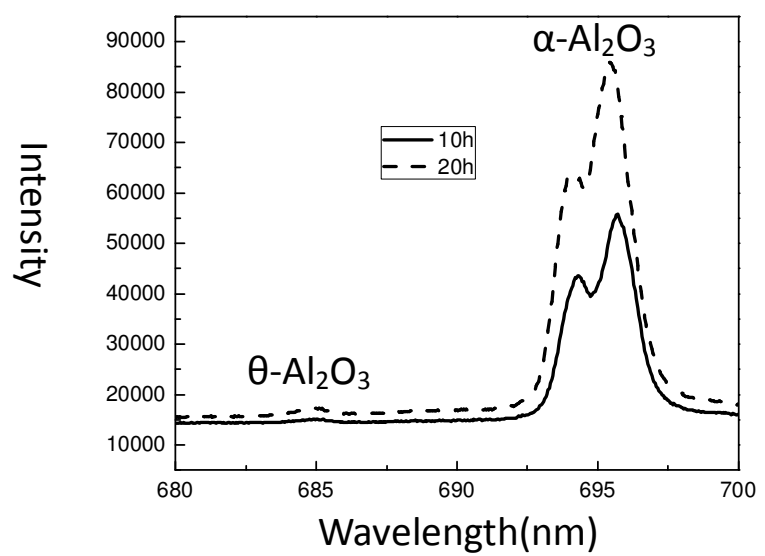

Figure 7 PSLS spectra from the scales formed on model alloy during isothermal oxidation in high purity $\operatorname{Ar}\left(\mathrm{O}_{2}<1.4 \mathrm{ppm}\right)$ at $900^{\circ} \mathrm{C}$. 